\title{
Mrs. Gant and Miss Zilphia Gant: Two Faulknerian Women A Phenomenological View
}

By

Matti J. Savolainen

University of Tampere

"Miss Zilphia Gant" was published in a limited edition of 300 copies for The Book Glub of Texas in 1932. The same year witnessed the publication of Light in August which, in turn, had been preceded by the appearance of such accomplished novels as Sanctuary (1931), As I Lay Dying (1930) and The Sound and the Fury (1929). The critical silence, or outright neglect, with which "Miss Zilphia Gant" was greeted, can to an extent be attributed to the virtual unavailability of the story until it was included in The Uncollected Stories of William Faulkner in 1979.1 The story shows Faulkner's continuing interest in feminine psychology ${ }^{2}$, especially in the disturbed female psyche, as also evident in such mentally paralysed characters as Rosa Goldfield (Absalom, Absalom!), Emily Grierson ("A Rose for Emily") and Minnie Cooper ("Dry September"). A profitable approach to an analysis of this kind of mentality is, I suggest, to focus on the way the protagonist perceives her surroundings, the world she lives in and the way she experiences herself and other people, the manner she relates to the temporal aspect of her being in the world.

The categories of World, Body, Fellow Men, and Time which I shall employ to discuss "Miss Zilphia Gant" are appropriated from The Phenomenological Approach to Psychiatry by Van den Berg. ${ }^{3}$ Brodtkorb applied the Dutch psychiatrist's categories in his study of Moby Dick (Ishmael's White World) and argued for their general validity and acceptability on the grounds that they are primarily existential categories rather than metaphysical ones. ${ }^{4}$ Even though the categories overlap, they provide a viable framework with which to analyse the story. 


\section{World}

In the phenomenological attitude the relationship betwecn man and the world can be defined in the following way:

The world is not an object such that I have in my possession the law of its making; it is the natural setting of, and field for, all my thoughts and all my explicit perceptions, ... there is no inner man, man is in the world, and only in the world does he know himself.

The relationship of man and world is so profound, that it is an error to separate them. ... The world is no conglomeration of mere objects to be described in the language of physical science. The world is our home, our habitat, the materialization of our subjectivity. ${ }^{5}$

The world, as directly experienced, is the reality which we confront and which confronts us. We have access to the world only through our point of view, and therefore our perception of it is always colored by our subjectivity, our individual rapport with the world.

The way in which the world appears to the two Faulknerian women is the immediate reality to them, that is, one of isolation, confinement, emptiness. The scope of the mental and physical space in which they are able to move is drastically limited. While Jim Gant, a horse and mule trader, can move about in the adjoining counties and even visit Memphis, Mrs. Gant, with her little daughter, is tied to the shabby hamlet "in a remote section of a remote county" (p. 369). Most of the time her husband is away from his family and he finally leaves his wife for another woman. Mrs. Gant is both physically and mentally cut off from other people: she has not been further away from her house than Jefferson; she does not read magazines and she has never seen a moving picture. There is irony in the fact that her husband's elopement causes Mrs. Gant to take direct action: she moves to Jefferson and buys a dressmaking shop to make her living.

Despite the physical change from the remote hamlet to the county seat there is no development in Mrs. Gant's relationship with her surroundings. She and her daughter live in a single room at the back of the dressmaking shop for twenty-three years. The room is furnished with the bare necessities: a bed, a table, two chairs, a stove. Objects, such as the sewing machine, are objects which Mrs. Gant can make direct use of. Her daughter hardly has toys to play with: once after Zilphia had started crying at the sight 
of a miniature stove her mother had bought for her, she took the toy back and made the seller return the money.

As an adult, Mrs. Gant is to a greater extent responsible for her own imprisonment than little Zilphia is for hers, because from the very beginning the child is at the mercy of her mother. The community where Mrs. Gant and her daughter live is not totally unsympathetic towards them: its interest in their affairs is not only one of curiosity but also concern and pity, even if from a distance. Individually the neighbours do not interfere even when they see that Mrs. Gant is supressing her daughter's normal development. Under her strict and undeviating supervision Zilphia has hardly any contacts with her peers. The timid pale girl does not go to school until a county health officier intervenes. The room at the ,dressmaking shop is a prison to Zilphia but it is also a kind of perverse sanctuary: she is so poorly equipped to cope with the world outside the shop that anything inside it is less frightening. She even wants to stop going to school because she is ashamed to be seen always accompanied by her mother. When all attempts to break loose from her mother's dominance have been defeated she projects her loneliness and despair into a physical disease. The mother's hold over her daughter is so strong that Zilphia leaves her husband because of her. The young woman is both literally and figuratively locked in. The image of a closed space (an unfrequented house, a room with barred windows, a locked door) becomes one of mental imprisonment, of enclosed consciousness. It is a consciousness in a vacuum, suffocating itself.

Zilphia cannot escape from her mental prison even after her mother's death. In fact her inner reality loses all contact with the objective world and becomes the only reality to her, a reality of day-dreams, nightmares, obsessions. The horizon opening to the world (shared by other people) is remarkably distorted, to the point of paranoia.

\section{Body}

Man is identical with his body, through which he interacts with the world and exerts a continuous dialogue with his surroundings. ${ }^{6}$

The physiognomy of Mrs. Gant is one of hard determination, unyielding strength and invulnerability. The outraged woman looks up her husband in Memphis with "the capability of a man, the pertinacity of a Fate, the serene imperviousness of a vestal out 
of a violated temple" (p. 370), and, as the text implies, shoots him dead. When she returns to her child, her face is "cold, satiate and chaste" (p. 370). Whilst keeping watch over Zilphia on the schoolground, she stands "upright, erect in a shapeless dress of dull black ... still comely in a harsh way" (p. 371). Her posture and her simple clothing reflect her mental rigidity and inflexibility. With the years her outward appearance turns into that of a man, at forty there is a faint shadow of a moustache at the corner of her mouth. Her sense of femininity is suppressed and replaced by a shield of masculinity - a shield with which to protect herself and her daughter from the approaches of men. The image of a vestal of a violated temple is appropriate in Mrs. Gant's case: her sanctuary lies in her serene and cold imperviousness. Her identification with her body is severely hampered, her identity and mental ntegrity lost (tellingly we never learn Mrs. Gant's first name). Mrs. Gant starts to hate her own femaleness because it had been violated by her husband, a man who most of the time neglected nis family and finally ran away altogether.

It is as if Mrs. Gant's body had betrayed her, and it is exactly his sense of the debased body that she projects onto her daughter. Her sense of debased womanhood is connected with her intense iatred of the male sex. Mrs. Gant insists on examining the bodily levelopment of Zilphia, who is approaching puberty:

the made Zilphia strip naked and stand cringing before her while the savage ight fell through the bars and the gray winter drove above the lot. After one of these examinations ... she told Zilphia what her father had done and what he had done. She sat on the bed while Zilphia cringed swiftly into her clothes, elling her about it in a cold, level voice, in the language of a man while Zilphia's hin body shrank and shrank as though in upon itself, as though at the impact of the words (p. 373-374).

3ody and sex are evil; they have to be fought. Zilphia loses contact vith corporeality: her body become alien to her, an object that he has to master according to the rules set by her mother. The zody in its sexual being is one way of interacting with the world ${ }^{7}$ sut to Zilphia this way is obstructed. She hides her inner self sehind "her small tragic mask of a face" (p. 372). The townspeople hink Zilphia as "a neat woman, with neat hair" (p. 375) even if he is forced to wear the simple clothes her mother has devised for 1er. Zilphia's own estimation of her attractiveness is practically nil. In the end Mrs. Gant cannot prevent Zilphia from meeting a nan, a painter who falls in love with her and wants to save her 
from the grip of the grim old woman. After their marriage Zilphia starts to hesitate in her decision to leave her mother. The confrontation of the three people in front of Mrs. Gant's house is crucial: like mesmerized, Zilphia turns her back on her husband, never to see him again, and enters the house. The connection between her volition and her body is cut off: "She seemed to have shrunk into herself, collapsing from inside, to have lost height, become awkward" (p. 377). Zilphia's body reacts in a similar way to the time when she was savagely examined by her mother, her body shrinking and crawling in upon itself. Mrs. Gant, armed with a shotgun, not only secures entry to the house, but also certifies Zilphia's ultimate imprisonment and mental cul-de-sac.

Gradually Zilphia falls into a state in which she has no regard for her body and, through it, for her immediate surroundings. She puts on weight and neglects her personal hygiene. Dreams of her husband pervade her consciousness, the smell of turpentine, associated with her husband, haunts her incessantly. h her sexual frustration she masturbates, whispering furiously: "Mary did it without a man. She did it; ... I will conceive! I'll make myself conceive!" (p. 379).

As her mother had spied upon her, now Zilphia has a private detective agency to report to her on her ex-husband who had remarried. She gains intimate knowledge of the young couple's life and is vicariously immersed in it:

Sometimes at night she would become one of the two of them, entering their bodies in turn and crucified anew by her ubiquity, participating in ecstasies the more racking for being vicarious and transcendant of the actual flesh (p. 380).

For Zilphia, her body in fact transforms itself into the body of another, and performs sexual acts which are the more real and ecstatic because they are imaginary. After learning of the wife's pregnancy, Zilphia punishes herself by taking some rat poison. Even after the baby's birth she would go on having nightmares periodically, also for a time dreaming of negro men. When after three years she returns to Jefferson with a child (the real parents of the child being dead), Zilphia has completely assumed the role of a mother: to her, the child is her flesh and blood as if she had given birth to it herself. The townspeople believe her fabricated story about her new marriage and the death of her husband, but out of habit they still call her Miss Zilphia Gant. Her subjectivity permeates the phenomena and states of affairs around her - it is 
the reality for her, even if from the factual, objective point of view her behaviour is based on a lie. Her sexual impulses are levelled out, compensated by and channelled into taking care of her little daughter and indulging in good food.

\section{Fellow men : communication}

Human beings share the world with other human beings. When man feels closeness and "togetherness" with another man, both of them have an intimate rapport with the world. "The relation $f$ man with man becomes real in the physiognomy, the vicinity or the distance, $₫$ world and body"? Sharing the world is established through communication.

It is evident that Mrs. Gant has no communication with other people in the normal sense. Her ability to express herself verbally is limited: her vocabulary, for the most part, consists of curses, short commands, denials. Her words are aggressive, harsh: when she unveils the facts of human sexual behaviour to Zilphia, she speaks in the cold, level voice of a man to the effect that Zilphia's frail body reacts physically to the words. The word "love" does not exist in her vocabulary. Mrs. Gant's words are few but they function like monstrous tools to shape their object. She needs only to call her daughter's name and Zilphia, as if paralyzed, yields to her will. When there is no need for words, she uses physical strength: she beats the half-wit who comes to collect his pay, she beats Zilphia not infrequently, she forces a client out of her dressing shop and throws an unfinished garment in the client's face.

In the relationship between Mrs. Gant and Zilphia the lack of verbal communication results in actual silence. It is a silence filled with unspoken distrust, fear, menace. The two women could sleep in the same bed and eat the same food for days in complete silence. Occasionally Zilphia could escape from under her mother's eye, but whenever the mother found her walking aimlessly on the outskirts of town, they returned home together without uttering a word. In the crucial scene in which Mrs. Gant separates Zilphia from her newly-wed husband, the closed door becomes a symbol of noncommunication, separation from the world of other people:

Zilphia shut the door carefully, fumbling a little at the knob. The house was still; in the cramped hall the shadows of the twilight loomed like a herd of motionless elephants. She could hear her heart faintly, but no other sound, no sound from beyond the door which she had closed upon her husband's face. She never saw it again (p. 377-378). 
The image of the silent house is powerful because of the finality of Zilphia's decision; the twilight that fills the hall "like a herd of motionless elephants" implies a threat and underlines the incongruity of her act.

Being mentally imprisoned by her mother Zilphia cannot learn to express herself verbally. Her first dates with a school-boy are innocent, wordless attempts to discover a common language, but all that they can do is to lie rigid, side by side, totally silent. In the story it is Zilphia's fiancé who argues and persuades - who uses language for a certain aim. Zilphia's participation in the dialogue is slight. Zilphia is better equipped to converse with imaginary people in the newspapers than with real people. Her distance from her own body is analogous with her distance from other people. After her return to Jefferson with the adopted child, Zilphia stops to chat and gossip with the ladies on the street but her talk is trivial, ha mless. At the end of the story Zilphia has established on some superficial level a contact with her surroundings but her situation is ambiguous nevertheless: she has either grounded her present life on a lie, forgetting her past, or she actually believes that her past was of the kind that she made it to be.

\section{Time : past and present}

In the phenomenological attitude past and future have a present value, they lie contained in the present. Through the double horizon of retention and protention the present ceases to be a factual present which is carried away and abolished by the flow of duration. ${ }^{9}$

The free flow of time, natural time - as exemplified by the industrious dusty sparrows (p. 371 and 377) - and the slow unhurrying movement of the little country-town's activities lie outside the subjective time as experienced by the two Faulknerian women. The fact that Jim Gant deserted his family is something that Mrs. Gant can never forget and forgive. Her revenge cannot wholly alleviate the outrage and insult she has experienced. Her present action is totally regulated by her past; her existence is a continuous merging of past and present. The consciousness which is enclosed upon itself has no future. Mrs. Gant's world is carried forward only by the continuation of her past which traces out in advance the style of what is to come. The very presence of Zilphia reminds Mrs. Cant of her former life,, the past she cannot accept. Because 
she is stuck with her own past she will do her utmost to block the horizon opening to the future for Zilphia.

Zilphia's struggle for identity and survival can be interpreted as an attempt to deny her mother's sense of time. After refusing to go to school Zilphia is compelled to remain in her mother's dressmaking shop for twelve years. During that period she would make wedding-gowns for her former school-friends, and a little later, clothes for their children. From her vantage point at the window she could watch the world go by, experience the past changing into the future only from the outside. Her behavior becomes ritualized: she spends her eventless days in "the slow mechanical manipulation" of her needle (p. 375); it is "the safe ritual of her fingers" that fills the void in her inner being (p.378). For a moment the future was open to Zilphia in the person of her husband, but she failed in the crucial test.

Zilphia's mind, on the other hand, is also filled with daydreaming. She creates out of herself and her husband fictitious characters who are "like dolls, furious and tragic but quite dead" (p. 378). The smell of turpentine literally obliterates time since it always brings along a very strong sense of her husband. Zilphia is in a circle in which the present transforms into her past and the past transforms into her present. Yet, in a perverse sense, she does break out of this circle by living in proxy the life of her ex-husband's wife through the reports issued by the detective agency. Even if this time-dimension opens up to the future, it does not relate to her actual situation. It is only an imaginary future but one with which Zilphia is so obsessed that it actualizes for her in her consciousness. Hers is a double life: one part of Zilphia is numbed with a mechanical daily routine, the other surges forward in the shape of another woman.

Zilphia extricates herself from her past simply by denying its existence. When she returns to Jefferson with the daughter of her ex-husband, it is as if she had obliterated all the intervening years between her own hasty marriage and the birth of her ex-husband's child. At one point she changes the pattern that Mrs. Gant had set for her: the room behind the dressmaking shop, her mental and physical prison, is transformed into a day nursery. In contrast to her own childhood Zilphia's adopted daughter has a great many playmates to keep her company. Yet, Zilphia cannot admit to her lady-friends or even to herself the extent of the isolation and loneliness that she experienced in that particular room. She denies 
some aspects of her past at the expense of not being able to participate fully in the present and look meaningfully forward to the future. Her dressmaking flourishes and she establishes a more or less respectable position in the eyes of her neighbours. However, the ending of the story is somewhat ambiguous: it is probably symptomatic that at the end we have the image of a woman escorting her little daughter on the way to and from school, dressed in her coat, "revealing her sewing apron of black oil cloth, and the straight thin glints of needles in her black bosom and the gossamer random festooning of the thread" (p. 381). This is exactly the attire that grim Mrs. Gant used to wear.

The purpose of this essay has not been to speculate upon Faulkner's attitude to his characters or the reasons why he may have chosen to write a story of the two mentally disturbed women. ${ }^{10}$ In particular, the aim was to perceive the characters from the inside, to delineate and analyse the limits and the scope of their lived worlds, with their distortions and obsessions. In the phenomenological perspective, the way in which the world articulates and constitutes itself in the consciousness of Mrs. Gant and her daughter is the ultimate, tangible reality for them, however much it may differ from the world which we assume as real. Once we as readers accept the specific character of this world, it turns out to be more accessible and comprehensible, opening up to and confronting the experience which we possess of our own worlds.

\section{NOTES}

1 Joseph Blotner, ed.: The Uncollected Stories of William Faulkner (New York: Random House, 1979), pp. 368-381. The subsequent references in the text are from this edition. The Book Club of Texas-edition is the original Miss Zilphia Gant (Dallas: J. M. Colville \& Son, 1932).

2 Cleanth Brooks, William Faulkner, Toward Yoknapatarepha and Beyond (New Haven: Yale University Press, 1978), p. 152. For a book-length study on Faulkner's feminine characters, see Sally R. Page's Faulkner's Women: Characterization and Meaning (Everet/Edvards Inc., 1972). In her book Mrs. Page discusses "Miss Zilphia Gant" under the heading "Sexual Perversity and Sterility", see esp. pp. 96-99.

3 J. H. Van den Berg, The Phenomenological Approach to Psychiatry, An Introduction to Recent Phenomenological Psychopatology (Springfield: Charles C. Thomas, 1955). 
4 Paul Brodtkorb, Jr., Ishmael's White World, A Phenomenological Reading of Moby Dick (New Haven: Yale University Press, 1965), p. 152.

5 The quotations come from Maurice Merleau-Ponty, Phenomenology \& Per-. ception, Trans. Colin Smith, (London: Routledge \& Megan Paul, 1978), p. xi and from Van den Berg, 1955, p. 32. In phenomenology the concept of the lived, directly experienced world holds a central position. Van den Berg's. formulation goes back to Heidegger's in-der-Welt-Sein and Husserl's Lebenswelt, Merleau-Ponty relies heavily on Husserl. Also Lauri Rauhala in his.

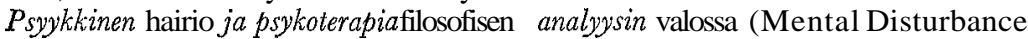
and Psychoterapy in Philosophical Analysis) (Tapiola: Weiling \& Göös, 1974) discusses the lived world in Heideggerian and Husserlian terms; see e.g. pp. 43-44 and 47-76.

6 Van den Berg, 1955, e.g. pp. 39 and 59.

7 Merleau-Ponty, 1978, pp. 154-173.

8 Van den Berg, 1955, p. 57.

9 Ibid, p. 71 and Merleau-Ponty, 1978, p. 84. The terms retention and protention Merleau-Ponty borrows from Husserl, see ibid. p. 416.

10 Cf. e.g. Henry Smith, who in his preface to Miss Zilphia Gant (1932) tended slightly to psychoanalyse Faulkner's writings in general. Smith wrote that Faulkner "seems often to be battling publicly with something deep and hostile within himself which he can not see or define. ... He habitually chooses people who are undisciplined by any civilized pattern, and makes their savage, bewildered struggles the expression of his own inner conflict" p. x. A recent book-length study on the relation between Faulkner's life and his fiction is David Minter's William Faulkner, His Life and Work (Baltimore and London: The Johns Hopkins University Press, 1980). Even if in general the study is a thorough and detailed one it omits "Miss Zilphia Gant" altogether. 